Abstract-Fishing activities on charter boats that targeted reef fishes were documented by observers in 2012 and 2013 to examine the effect of fishing season (open versus closed) for red snapper (Lutjanus campechanus) on fishing effort, catch, and discard variables. During 54 trips of charter boats with observers, 38 species of fishes were identified; 32 trips were taken during red snapper open seasons and 22 trips were taken during closed seasons. The majority of the catch and discards comprised lutjanids but also included small demersal reef fishes, highly migratory pelagic fishes, and elasmobranchs. Boat captains targeted artificial reefs at depths $<40$ $m$ with red snapper abundances that were higher and species diversity that was lower during open seasons than the abundances and diversity found at deeper natural reefs that were fished during closed seasons. On closed-season trips, distance from shore, number of sites fished, and time fished per site were greater, whereas the number of fishermen was significantly lower than the number on open-season trips. The number, size, and proportion of red snapper caught were significantly greater during open-season trips than during closed seasons, but the number of red snapper discards was not significantly different between seasons. This study supports the use of onboard observer programs for the collection of accurate and reliable catch, effort, and discard data regarding the recreational for-hire sector, and for identifying changes in fishing strategies and behavior between closed and open seasons for the red snapper fishery in the northern Gulf of Mexico.

Manuscript submitted 2 June 2014. Manuscript accepted 4 February 2015. Fish. Bull. 113:157-166 (2015). doi: 10.7755/FB.113.2.4

The views and opinions expressed or implied in this article are those of the author (or authors) and do not necessarily reflect the position of the National Marine Fisheries Service, NOAA.

\title{
Direct observation of fishing effort, catch, and discard rates of charter boats targeting reef fishes in the northern Gulf of Mexico
}

\author{
Steven B. Garner (contact author) \\ William F. Patterson \\ Email address for the contact author: sgarner@disl.org \\ University of South Alabama and \\ Dauphin Island Sea Lab \\ 101 Bienville Boulevard \\ Dauphin Island, Alabama 36528.
}

Fisheries bycatch and discards affect marine ecosystems worldwide, constituting as much as $25 \%$ of the annual global catch (Alverson et al., 1994; Kelleher, 2005; Matsuoka, 2008). The ethical issue of wasted marine resources, as well as the negative impacts that discards can have on fishes and ecosystems, warrants efforts to minimize discards and mitigate their effects (FAO, 1995; Kennelly and Broadhurst, 2002; MSFCMA 2007; NMFS, 2011). To that end, initiatives to minimize bycatch and discards have been fostered by the United Nations, European Union, and United States (FAO, 1995; European Commission $^{1}$; Hermes ${ }^{2}$. Under U.S.

\footnotetext{
${ }^{1}$ European Commission. 2008. Overview of the contributions received in answer to the consultation on the implementation of the policy to reduce unwanted by-catch and eliminate discards in European fisheries. Working document of Directorate-General for Maritime Affairs and Fisheries, 6 p. [Available from http://ec.europa.eu/dgs/maritimeaffairs fisheries/consultations/discards/.]

${ }^{2}$ Hermes, R. 2009. Terminal evaluation of the UNEP/GEF project. Reduction of environmental impact from tropical shrimp trawling through the introduction of bycatch reduction technologies and change of management, $30 \mathrm{p}$. United Nations Environment Programme Evaluation and Oversight Unit, Nairobi, Kenya. [Available from http://www. unep.org/eou.]
}

federal fisheries management, $\mathrm{Na}$ tional Standard 9 of the MagnusonStevens Fishery Conservation and Management Act (MSFCMA, 2007) mandates that bycatch and discard mortality be minimized to the lowest "extent practicable."

Complying with MSFCMA mandates has been difficult in the fishery for reef fishes in the northern Gulf of Mexico (GOM) because of high fishing effort and the diversity of fisheries that target reef fishes or catch them as nontargeted bycatch (Coleman et al., 2004; Hanson and Sauls, 2011; Cowan et al., 2011). Data on discards in the northern GOM recreational fishery are collected by multiple fishery monitoring programs, including the Marine Recreational Information Program, Southeast Region Headboat Survey, and Texas Parks and Wildlife Department Coastal Creel Survey (Chromy et al. ${ }^{3}$ ). However, in all of these surveys, discard numbers and the disposition of catch (live or dead) are entirely self-reported by

${ }^{3}$ Chromy, J. R., S. M. Holland and R. Webster. 2009. Consultant's report: For-hire recreational fisheries surveys, 60 p. Submitted to the For-Hire Work Group, National Marine Fisheries Service. [Available from http://www.countmyfish.noaa.gov/projects/downloads/ MRIP_FHWG\%20ForHire\%20 Methods\%20Review\%20Final.pdf.] 
fishermen. This reliance is problematic because recall bias can greatly reduce the accuracy and precision of discard estimates (Ditton et al., 1978; Holland et al., 1992; Hanson and Sauls, 2011; Bochenek et al., 2012; Donaldson et al. ${ }^{44}$ ). Uncertainty in estimates of biological parameters may increase the risk of fisheries exceeding annual quotas or decrease their value for assessment models (Patterson et al., 2001a). Onboard observers, on the other hand, provide direct estimates of catch and discards that can be used to verify and adjust fleet-wide estimates input into stock assessments (Kennelly and Broadhurst, 2002; Bochenek et al., 2012; Donaldson et al.4; Sauls, 2014).

The purpose of this study was to employ onboard observers to directly estimate effort, catch, and discards in the for-hire recreational fishery for reef fishes in the northern GOM. A focus of this study was the red snapper (Lutjanus campechanus), which is the most highly targeted reef fish in the region and for which the estimated ratio of total harvest (landed catch plus dead discards) to landed catch has averaged 1.5:1.0 in recent years $\left(\mathrm{SEDAR}^{5}\right)$. A simple protocol was developed to incorporate observers into normal fishing operations onboard charter boats 1) to provide estimates of effort, catch, and discard variables on trips that targeted reef fishes, 2) to characterize changes in fishing behavior and catch for both open and closed seasons for red snapper, and 3) to examine differences in the size and age composition of discarded red snapper for both open- and closed-season trips.

\section{Materials and methods}

Observers collected data during fishing operations on charter boats during 2012 and 2013, working onboard 4 vessels that operated out of home ports between Destin, Florida, and Orange Beach, Alabama, the historical center of for-hire effort in the northern GOM red snapper fishery $\left(\mathrm{SEDAR}^{5}\right)$. Boat captains were contacted each week to obtain notice of a trip and to notify them of observer participation. Captains were compensated $\$ 250$ for each trip because the presence of an observer meant the loss of one potential customer. Captains provided the depth, reef type (artificial or natural), and approximate GPS coordinates for each site fished. Observers recorded the total number of fishermen onboard, the number of fishermen that fished at each site, the time spent fishing at each

\footnotetext{
${ }^{4}$ Donaldson, D., G. Bray, B. Sauls, S. Freed, B. Cermak, P. Campbell, A. Best, K. Doyle, A. Strelcheck, and K. Brennan. 2013. For-hire electronic logbook pilot study in the Gulf of Mexico: final report, 63 p. Report submitted to the Marine Recreational Information Program Operations Team. [Available from https://www.st.nmfs.noaa.gov/Assets/ recreational/pdf/Charter_Boat_Logbook_Project_report.pdf.]

5 SEDAR (Southeast Data, Assessment, and Review). 2013. SEDAR 31-Gulf of Mexico red snapper stock assessment report,1103 p. [Available from http://www.sefsc.noaa.gov/ sedar/.]
}

site, and the terminal tackle used to catch each fish. General comments were recorded with respect to the types of fishing rigs used (e.g., multiple-hook bottom rigs versus single-hook bottom rigs suspended in the water column), and the manufacturer, model number, and dimensions of circle hooks were recorded. A Letter of Acknowledgment from the National Marine Fisheries Service's Southeast Regional Office, in accordance with the definitions and guidance at Federal Register (2012), permitted observers to collect red snapper (of any size during any season) on the 4 vessels that participated in this study.

All fish captured during normal bottom fishing operations (i.e., excluding fish caught when a vessel was trolling to and from offshore sites) were identified to species (Hoese and Moore, 1998; FishBase, http://www. fishbase.org), weighed to the nearest $0.1 \mathrm{~kg}$, and measured in fork length (FL) and total length (TL) to the nearest millimeter. Observers recorded whether fish were retained or discarded. Species that were identified but accidentally released without having been measured (i.e., fish that escaped when they were hoisted into a boat) or could not be brought aboard (i.e., large elasmobranchs) were recorded and included in that trip's discard total. A sample of red snapper discards was collected at each site during both open and closed seasons. These fish were systematically and randomly sampled through retention of every $n$th fish, depending on catch rate, such that approximately 20 discarded red snapper were sampled on each trip. A similar systematic sampling routine was employed to sample approximately 20 red snapper retained by fishermen as landed catch during each open-season trip. All sampled fish were identified by affixing a numbercoded plastic cable tie through the opercular and buccal cavity of each fish.

The retained catch from each vessel was processed by the crew at the dock. Carcasses from those fish, as well as whole discards, were transported back to the laboratory at the Dauphin Island Sea Lab. Otoliths were collected from all fish and processed for aging. Otoliths were rinsed of adhering tissue and stored dry in plastic cell wells; they were then embedded in epoxy, sectioned with a low-speed wafering saw, and aged according to standard protocols (Patterson et al., 2001b). Opaque zones were counted by 2 independent readers and average percent error was calculated between reader counts (Beamish and Fournier, 1981).

Models for single-factor analysis of variance (ANOVA) $(\alpha=0.05)$ were computed in $R$, vers. 3.1.0 ( $R$ Core Team, 2014; Crawley, 2007; Kabacoff, 2011) to test the effect of red snapper fishing seasons, open versus closed, on effort (distance from port, depth, number of fishermen, number of sites fished per trip, time fished per site, and percentage of natural reefs fished), catch (number of species, fishes, and red snapper caught and percentage of the catch that was red snapper), and discard (number of discards for all fishes and red snapper only) variables. Data were ln-transformed to achieve normality and homogeneity of variances when necessary. 


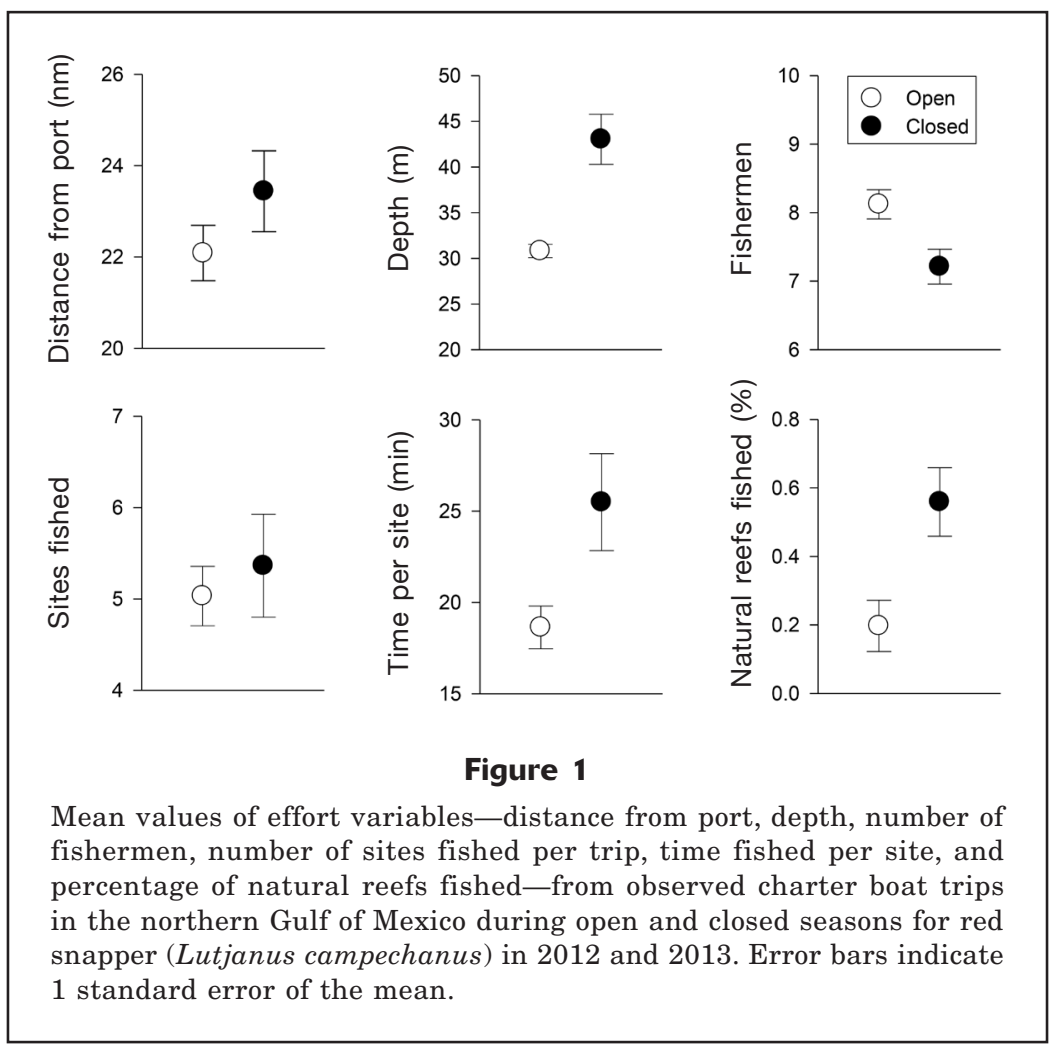

Differences in the species composition of the catch and discards for open and closed seasons were tested with permutational multivariate analysis of variance (PERMANOVA) in Primer 6 (PRIMER-E Ltd, Ivybridge, UK) with PERMANOVA+ (Anderson et al., 2008). The difference in TL and age among red snapper catch retained during open seasons, discarded during open seasons, or discarded during closed-seasons was tested with ANOVA, with differences among factor levels indicated by Tukey's honestly significant difference test. Lastly, ANOVA models were computed to test the effect of hook size on TL of caught red snapper, as well as on FL among all fishes caught during charter boat trips with observers aboard; per regulation, all hooks were nonstainless steel circle hooks. Hook size categories were based on the measurement of hook front length, defined as the distance from hook point to initial bend back toward hook shank: small $(<20 \mathrm{~mm})$, medium $(\leq 20$ $\mathrm{mm}$ and $>25 \mathrm{~mm})$ and large $(\geq 25 \mathrm{~mm})$.

\section{Results}

Observers collected data on 24 charter boat trips in 2012 and on 30 trips in 2013; 32 trips occurred during red snapper open seasons and 22 trips occurred during closed seasons. Differences between open and closed seasons were observed for several parameters of effort (Fig. 1). During closed seasons, the mean depth of sites fished was 28\% greater (ANOVA,
$\left.F_{1 ; 262}=24.0, P<0.001\right)$, trip duration increased by $31 \%$ (ANOVA, $F_{1 ; 52}=8.55, P=0.005$ ), and the percentage of natural reefs fished increased nearly 3 -fold (ANOVA, $F_{1 ; 52}=76.32, P<0.001$ ), compared with values observed during open seasons. Mean distance from port (ANOVA, $\left.F_{1 ; 259}=1.70, P=0.193\right)$ and number of sites fished (ANOVA, $F_{1 ; 5} 2=0.297, P=0.588$ ) were greater during closed-season trips than during open-season trips, but differences between seasons were not statically significant. The only effort parameter that decreased significantly during closed-season trips was the mean number of fishermen (ANOVA, $F_{1,277}=7.56, P=0.006$ ), which decreased by $11 \%$.

The 2 predominant fishing rigs used during observed trips were 1) a single, large hook $(\geq 9 / 0)$, fished with large bait attached to a long leader suspended in the water column (rig type I) or 2) multiple, small hooks fished with small, cut bait attached to short leaders fished at or near the bottom (rig type II). Rig type I was typically fished with large bait $(\sim 15-20 \mathrm{~cm}$ TL) that was dead or live (e.g., Atlantic mackerel [Scomber scombrus], mackerel scad [Decapterus macarellus], or gulf menhaden [Brevoortia patronus]); the choice to use large bait was intended to increase catch rates of relatively large $(>500 \mathrm{~mm}$ TL) red snapper targeted during open seasons. Fishermen almost exclusively used rig type I during open seasons, until they filled their daily bag limit for red snapper. Fishermen would then switch to targeting other fishes with rig type II until that day's trip time had expired; however, this fishing 
Table 1

Species-specific percentages of total catch and discards observed during charter boat trips in the northern Gulf of Mexico during open and closed seasons for red snapper (Lutjanus campechanus) in 2012 and 2013.

\begin{tabular}{llrrrr}
\hline & & \multicolumn{2}{c}{ Catch } & \multicolumn{2}{c}{ Discards } \\
\cline { 3 - 6 } Common name & Species & Open & Closed & Open & Closed \\
\hline \multirow{2}{*}{ Red snapper } & Lutjanus campechanus & 76.6 & 23.3 & 89.8 & 63.3 \\
Vermilion snapper & Rhomboplites aurorubens & 11.9 & 33.7 & 2.5 & 2.3 \\
Red porgy & Pagrus pagrus & 3.9 & 15.3 & 0.2 & 0.0 \\
Gray triggerfish & Balistes capriscus & 1.7 & 7.8 & 5.5 & 18.6 \\
Tomtate & Haemulon aurolineatum & 1.3 & 5.9 & 0.0 & 0.0 \\
Greater amberjack & Seriola dumerili & 0.7 & 5.3 & 0.0 & 5.5 \\
Banded rudderfish & Seriola zonata & 0.0 & 2.0 & 0.2 & 5.5 \\
Whitebone porgy & Calamus leucosteus & 0.1 & 1.2 & 0.0 & 0.0 \\
Scamp & Mycteroperca phenax & 0.7 & 1.0 & 0.6 & 1.6 \\
Gag & Mycteroperca microlepis & 0.5 & 0.7 & 0.8 & 0.8 \\
Sharks & Carcharhiniformes & 0.1 & 0.5 & 0.2 & 1.2 \\
Other & & 2.6 & 3.2 & 0.3 & 1.0 \\
& & & & & \\
\hline
\end{tabular}

behavior occurred only aboard one vessel. During red snapper closed seasons, fishermen predominantly used rig type II to target smaller reef fishes (e.g., vermilion snapper [Rhomboplites aurorubens], red porgy [Pagrus pagrus], or gray triggerfish [Balistes capriscus]). During grouper open seasons, which overlap with red snapper closed seasons, it was common for one fisherman to target groupers with rig type I while the remaining fishermen targeted smaller reef fishes with rig type II.

The total catch on all observed charter boat trips was 2830 fish representing 38 species (Tables 1 and 2 ). Boat-side releases prevented accurate identifica- tion of several sharks. However, individuals that were identified to species included blacknose shark (Carcharhinus acronotus), sandbar shark (Carcharhinus plumbeus), scalloped hammerhead (Sphyrna lewini), and tiger shark (Galeocerdo cuvier). The mean number of fish caught per trip was $22 \%$ greater on trips during closed red snapper seasons than on trips during open seasons (ANOVA, $F_{1 ; 52}=2.57, P=0.115$ ) and on average more than twice as many species were caught on closed-season trips (ANOVA, $F_{1 ; 52}=22.50, P<0.001$; Fig. 2 ). During open-season trips, the number of red snapper caught was 2.6 times greater (ANOVA, $F_{1 ; 5}=28.90$, $P<0.001)$ and the percentage of the total catch that was

Table 2

Species of reef fishes that comprised $<0.1 \%$ of the catch or discards observed on charter boat trips in the northern Gulf of Mexico in 2012 and 2013.

\begin{tabular}{llll}
\hline Common name & \multicolumn{1}{c}{ Species } & Common name & \multicolumn{1}{c}{ Species } \\
\hline Almaco jack & Seriola rivoliana & Mahi mahi & Coryphaena hippurus \\
Great barracuda & Sphyraena barracuda & Manta ray & Manta birostris \\
Bank sea bass & Centropristis ocyurus & Red grouper & Epinephelus morio \\
Bigeye & Priacanthus arenatus & Red hind & Epinephelus guttatus \\
Blackfin tuna & Thunnus atlanticus & Sand tilefish & Malacanthus plumieri \\
Blue angelfish & Holacanthus bermudensis & Short bigeye & Pristigenys alta \\
Blue runner & Caranx crysos & Snowy grouper & Hyporthodus niveatus \\
Cobia & Rachycentron canadum & Spanish mackerel & Scomberomorus maculatus \\
Atlantic creolefish & Paranthias furcifer & Tattler & Serranus phoebe \\
Dwarf sand perch & Diplectrum bivittatum & Wahoo & Acanthocybium solandri \\
Little tunny & Euthynnus alletteratus & Yellowedge grouper & Hyporthodus flavolimbatus \\
King mackerel & Scomberomorus cavalla & & \\
Lane snapper & Lutjanus synagris & & \\
& & & \\
\end{tabular}




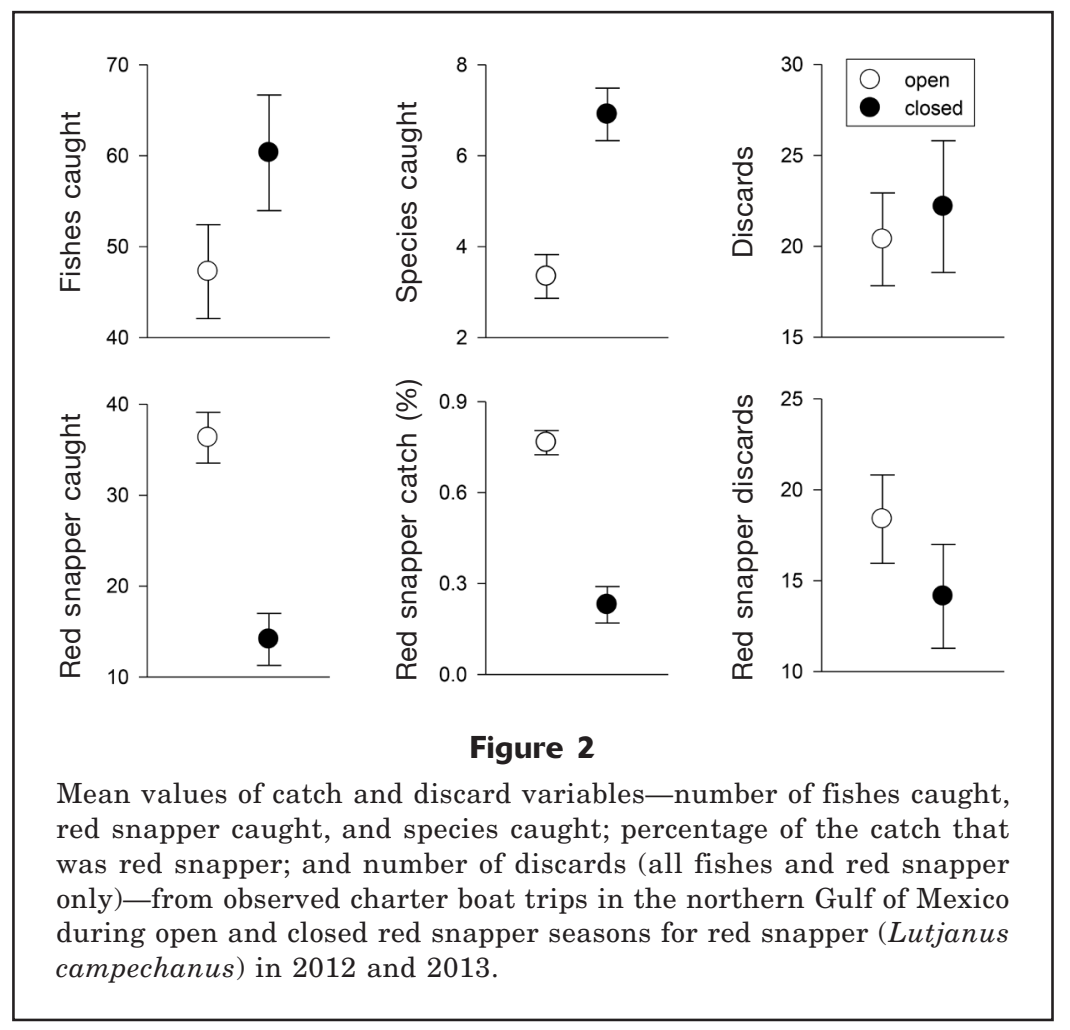

red snapper was 3.1 times greater (ANOVA, $F_{1 ; 52}=76.32$, $P<0.001)$ than during closed season trips. However, neither the total number of discards nor the number of red snapper discards was significantly different between open- and closed-season trips (ANOVA, $P>0.266$ ).

The species composition of the catch from charter boat trips was significantly different between red snapper open and closed seasons (PERMANOVA, pseudo$F_{1 ; 53}=21.46, P<0.001$; Table 1 ). Red snapper accounted for the highest percentage of the catch during openseason trips $(76.6 \%)$ and the second highest percentage during closed-season trips (23.3\%). Apart from red snapper, only vermilion snapper $(11.9 \%)$ contributed more than $10 \%$ of the catch on open-season trips; this species was sometimes targeted after the daily bag limit of red snapper was reached. The catch of vermilion snapper increased nearly 3-fold for closed-season trips in contrast to open-season trips, but even larger increases between seasons were seen for other species (Table 1). In fact, reef fishes (e.g., vermilion snapper, red porgy, and tomtate [Haemulon aurolineatum]) that were smaller ( $<350 \mathrm{~mm} \mathrm{TL})$ in size and lower in value than red snapper composed the majority (54.9\%) of the total catch for trips taken during the red snapper closed season. Pelagic species, primarily little tunny (Euthynnus alletteratus] and king mackerel (Scomberomorus cavalla), were caught infrequently $(<1 \%$ of the total catch) during normal bottom fishing activities during both open and closed seasons.

The species composition of discards from charter boat trips was significantly different between open and closed red snapper seasons (PERMANOVA, pseudo$F_{1 ; 51}=6.33, P<0.001$; Table 1 ). However, red snapper dominated discards from trips that occurred during both open $(89.8 \%)$ and closed $(63.3 \%)$ seasons despite lower catch rates in closed seasons (Table 1). Fishermen preference had a greater effect on red snapper discards during open seasons than did either minimum length limits or daily bag limits. Of the 583 red snapper discards recorded by observers during trips that occurred during open seasons for red snapper, 492 discards $(84.4 \%)$ were the result of fishermen discarding live, legal-size ( $\geq 406 \mathrm{~mm} \mathrm{TL})$ fish so that they could target larger fish for retention. Of the remaining discards of red snapper observed during open seasons, $13.4 \%$ were below the minimum length limit and $2.1 \%$ were discarded because fishermen already had reached their daily bag limit ( 2 fish per person per day). Mean TLs of red snapper were significantly different in comparisons among landed catch of red snapper retained during open seasons $(633 \mathrm{~mm}$ [standard error (SE) 4.0)]), open-season discards (475 mm [SE 3.4]), and closed-season discards (443 mm [SE 7.0]; ANOVA, $F_{2 ; 1,439}=511.8, P<0.001$; Fig. $3 \mathrm{~A}$ ), and mean values for all 3 groups were also significantly different in pairwise comparisons (Tukey's, $P<0.001$ ).

Discarding of other reef fishes was almost exclusively driven by seasonal closures and minimum length limits. For example, all gag (Mycteroperca microlepis) observed during this study were caught during closed seasons and were, therefore, discarded. No species, other than red snapper, were discarded as a result 

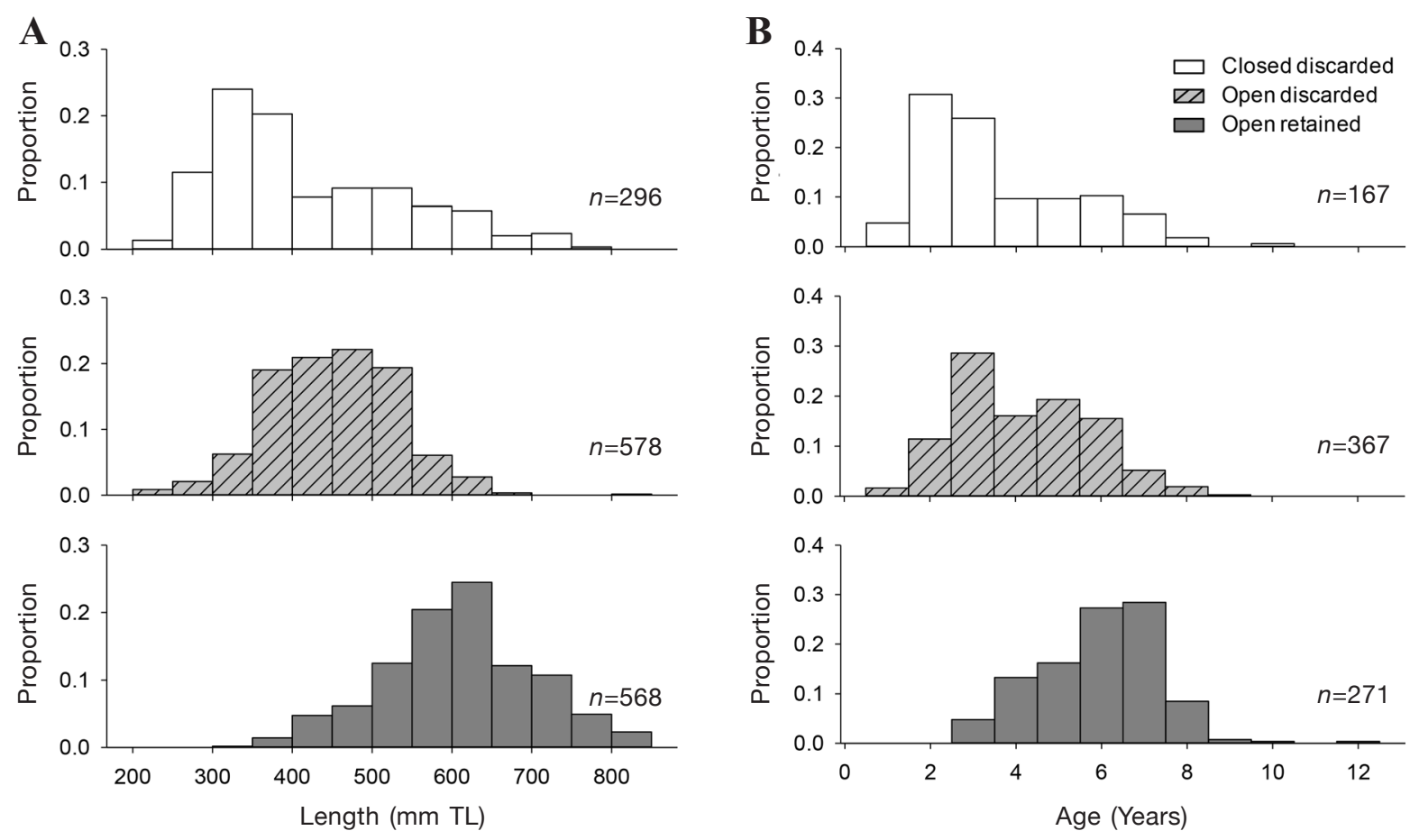

Figure 3

Frequency histograms of (A) size (total length [TL] in millimeters) and (B) age (years) of red snapper (Lutjanus campechanus) discarded during closed seasons (closed discarded) and red snapper discarded or retained during open seasons (open discarded) and (open retained) during observed charter boat trips in the northern Gulf of Mexico in 2012 and 2013. $n=$ the number of observations in each category (e.g., closed discarded).

of reaching the daily bag limit, except one, legal-size, greater amberjack (Seriola dumerili) that was discarded in 2012. In that case, 2 legal-size fish were caught simultaneously but only 1 fish was needed to fill the daily bag limit. Approximately half of the gray triggerfish $(54.3 \%)$ and greater amberjack (56.8\%) discards were the consequence of closed seasons for those species, and the remaining fish were discarded because of minimum length limits. No gag, greater amberjack, or gray triggerfish above their minimum length limit (559 $\mathrm{mm}$ TL, $762 \mathrm{~mm}$ FL, and $356 \mathrm{~mm}$ FL, respectively) were discarded when their respective recreational seasons were open and the daily bag limit was not yet filled.

Among the catch, red snapper ages ranged from 1 to 12 years, and average percent error between otolith readers was $1.31 \%$. Mean age was significantly different in comparisons of red snapper retained as landed catch during open seasons (7 years), open season discards (3 years), and closed season discards (2 years; ANOVA, $F_{2 ; 802}=139.30, P<0.001$; Fig. 3B). Red snapper TL was affected significantly by hook front length (ANOVA, $F_{2 ; 1,419}=160.10, P<0.001$ ), but TL was not significantly different between medium and large hooks (Tukey's, $P=0.360$ ), with mean red snapper TLs of 466 $\mathrm{mm}$ (SE 5.7) for small hooks, $565 \mathrm{~mm}$ (SE 5.1) for me- dium hooks, and $575 \mathrm{~mm}$ (SE 5.0) for large hooks (Fig. 4A). Similar to trends observed for red snapper, mean FL of all fishes caught on charter boat trips with observers was significantly different for small, medium, and large hooks (ANOVA, F2;2,674=894.20, $P<0.001$; Fig. 4B). Values of mean FL ranged from $355 \mathrm{~mm}$ (SE 2.8) for small hooks to $574 \mathrm{~mm}$ ( $\mathrm{SE} \mathrm{7.2)} \mathrm{for} \mathrm{large}$ hooks and were significantly different for all pairs of hook sizes (Tukey's, $P<0.001$ ).

\section{Discussion}

This study demonstrates the pervasive problem of discards in the reef fish fishery in the northern GOM, particularly for red snapper. During open seasons, captains of charter boats almost exclusively targeted fish at shallow artificial reefs (depths $<40 \mathrm{~m}$ ) where red snapper are highly abundant. During closed seasons, captains fished more frequently on natural reefs that, by comparison, had higher species diversity and lower red snapper abundances than those at the artificial reefs during open seasons, (Dance et al., 2011; Patterson et al., 2014).

Red snapper are ubiquitous at reef sites across the northern GOM and their aggressiveness toward fished 


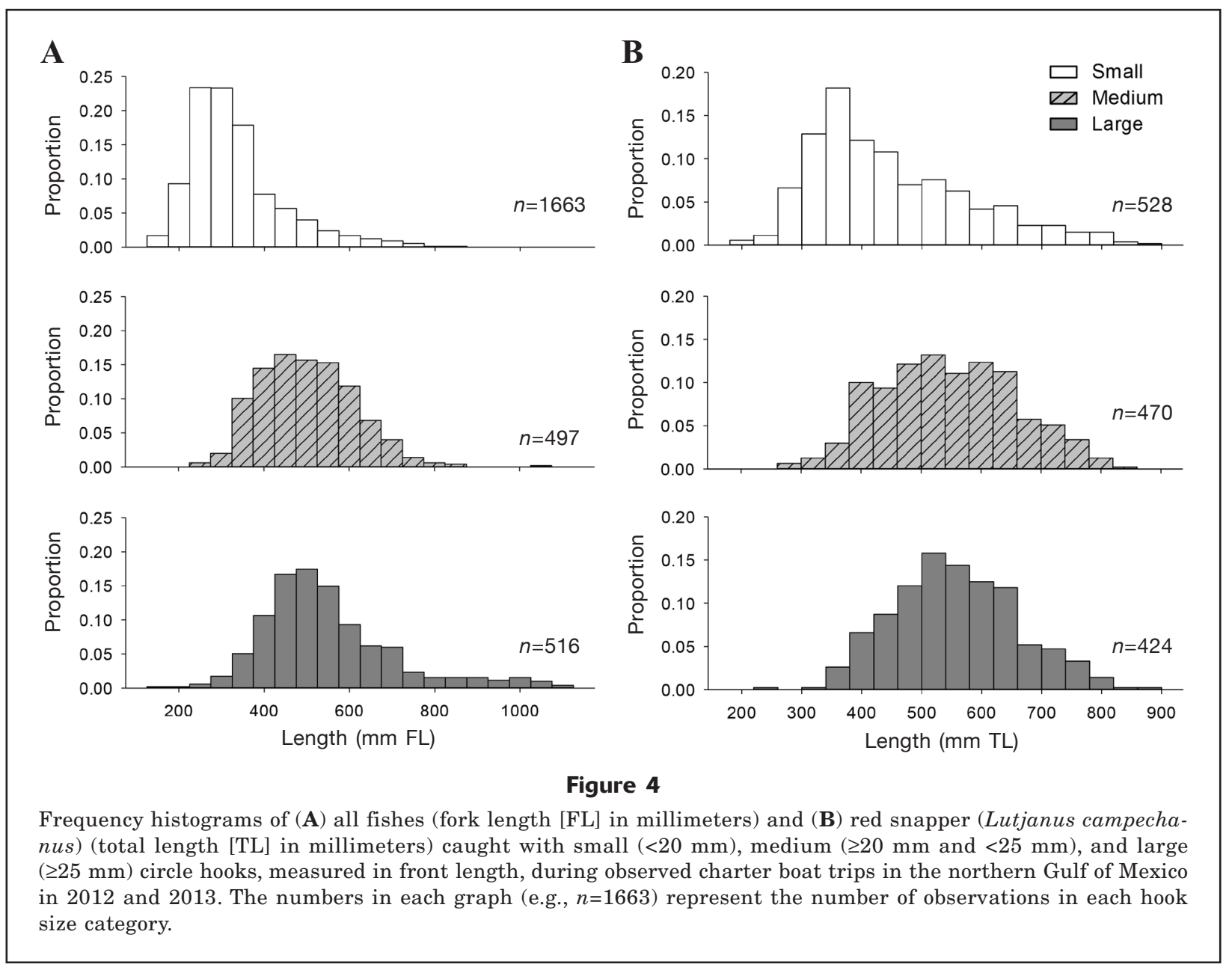

baits makes them difficult to avoid when targeting other species (Patterson et al., 2012). For red snapper catch and number of red snapper discards during the months of November and December, Schirripa and Legault ${ }^{6}$ reported declines of $22 \%$ and $46 \%$, respectively, for mean values from the period of 1993-1997 to the year 1998, the first year of the recreational red snapper season closure during those months. They concluded that recreational fishermen were able to effectively avoid red snapper; however, we suggest that the lower discard rate in 1998 for November and December, compared with the yearly average in 1993-1997, may be attributed to seasonal changes in fish behavior or distribution rather than to direct avoidance by fishermen. In our study, red snapper catch was $61 \%$ lower during closed seasons than during open seasons, but discards declined by only $23 \%$ and were not significantly lower during closed seasons.

\footnotetext{
${ }^{6}$ Schirripa, M. J., and C. M. Legault. 1999. Status of the red snapper in U.S. waters of the Gulf of Mexico: updated through 1998. Southeast Fish. Sci. Cent. Sustainable Fish. Div. Contrib. SFD-99/00-75, 86 p. [Available from http:// www.sefsc.noaa.gov/publications/.]
}

Several reasons exist for the difference between this study and that of Schirripa and Legault ${ }^{6}$ in the reported change in the number of red snapper discards for open and closed seasons. First, red snapper abundance has increased in the northern GOM since the late 1990s; therefore, more fish are available to be caught now (SEDAR ${ }^{5}$ ). Second, the daily bag limit for the recreational fishery has dropped from 5 to 2 fish per fisherman per day, increasing the potential for a greater number of discards. Lastly, fishermen's behavior clearly played a large role in discard rates in our study, particularly during open-season trips. The vast majority $(84.4 \%)$ of discards made during open seasons were of legal-size fish that were returned to the sea because fishermen wanted to catch larger fish to fill their daily bag limit. Discard rates during open seasons would have been substantially lower if each fisherman simply had retained the first 2 legal-size red snapper caught and then switched to targeting alternative species.

Targeting and discarding practices increased the difference in size and age composition between retained and discarded red snapper during open-season trips and between open and closed-season trips. The use of 
larger hooks and baits during open seasons also increased the mean size and modal age of red snapper compared with values observed during closed seasons. Patterson et al. (2012) and Sauls and Ayala (2012) also reported increased red snapper lengths and percentage of the catch that was red snapper, respectively, with increasing circle hook size. However, the effects of bait size, type, and hook size interactions were not tested by Patterson et al. (2012) and were confounded among explanatory variables tested by Sauls and Ayala (2012). Nonetheless, these parameters may explain the more dramatic increases in red snapper length with increasing hook size observed in our study than other studies.

High-grading (i.e., releasing fish of legal size in favor of potentially catching larger individuals) of live red snapper drove shifts in size (more than $150 \mathrm{~mm}$ TL) and age (4 years) between open-season discards and retained catch that were more dramatic than the differences would have been if the fishermen had retained the first 2 legal-size fish caught. High-grading of live fish was unique to red snapper catches in this study because no other retainable individual of any species other than red snapper was ever discarded by fishermen. The minimum length limit for red snapper is set at $406 \mathrm{~mm}$ (16 in) TL as a compromise between yield foregone to discard mortality and maximum yield per recruit (Waters and Huntsman, 1986; SEDAR ${ }^{5}$ ).

During observed charter boat trips, 38 species were documented in the catch, which included both overfished and protected fishes. In addition to the reefassociated species targeted directly, fishermen caught highly migratory pelagic fishes, small demersal reef fishes, and large elasmobranchs, all at variable rates. Catch rates for species other than red snapper were generally low, and overfished species (i.e., gag, gray triggerfish, and greater amberjack) were discarded because of either minimum length limits or closed seasons. High discard mortality of physoclistous fishes caught in deep waters (depths $>40 \mathrm{~m}$ ), combined with intense gulf-wide recreational fishing effort (Coleman et al., 2004; Hanson and Sauls, 2011), likely amplifies the impact of discarding practices during closed-season trips given the greater depths fished compared to openseason trips (Wilson and Burns, 1996; Coggins et al., 2007; Rummer, 2007; Campbell et al., 2014).

Without direct regulation of fishing effort, fishermen have maintained high levels of effort despite greatly reduced open seasons for red snapper. The MSFCMA requires that overfished stocks be rebuilt while bycatch and bycatch mortality simultaneously are reduced to the extent practicable (MSFCMA, 2007), but the current Gulf of Mexico Fishery Management Council (GMFMC) reef fish fishery management plan contains no direct management measures, or penalties, that regulate discard composition or rates in this fishery (GMFMC, 2004). Captains adaptively change fishing behavior and gear to maximize catch efficiency, but priority is placed on capturing target species rather than on minimizing bycatch and discards.
Alternative management measures, such as a slot size (i.e., fish can only be retained when their length is between an upper and lower limit), cumulative length limits, or a first fish rule, have been proposed to the GMFMC as strategies for reducing fishing mortality and discards in the recreational reef fish fishery (GMFMC, 2004). Significant depth-related discard mortality precludes the use of slot size limits in red snapper management (Rummer, 2007; Campbell et al., 2010; SEDAR5; Campbell et al., 2014). A first fish rule would allow vessels to retain all fishes caught until a singleor multiple-species daily bag limit is reached. A cumulative length limit regulation would set a daily length limit such that the sum of the lengths (e.g., TLs) of all retained individuals of a single species could not exceed (Bochenek et al., 2010; 2012).

In testing alternative regulations to bag and size limits, Bochenek et al. (2010) found that the cumulative length limit scenario decreased discard mortality by up to $63 \%$ and increased landings more than 2 -fold without increasing fishing mortality rates, compared with levels observed under status quo regulations, in the recreational fishery for summer flounder (Paralichthys dentatus) in New Jersey. However, the efficacy of these types of alternative management strategies for reduction of discards is contingent upon effort reduction and may not be successful if fishermen high-grade live fish or simply target additional species upon reaching the daily bag limit for their primary target species. Regardless of the management strategy used, incorporation of a means to verify and tune self-reported estimates (e.g., data from onboard observers) would prove valuable in reducing uncertainty in stock assessments, especially for the private sector, which contributes the majority of discards (74-84\% since 2008) in the fishery (Recreational Fisheries Statistics Queries, National Marine Fisheries Service Office of Science and Technology, http://www.st.nmfs.noaa.gov/st1/recreational/ queries/, accessed April 2014.).

The ability to high-grade live fish had an overwhelming effect on the size and age of red snapper retained during open seasons. Alternative regulations that could minimize or prevent high-grading live red snapper may actually improve angler attitudes by removing the negative connotations associated with dead releases and increasing the perceived value of retaining smaller, legal-size fish. A fundamental aspect of the charter boat industry is the ability of captains and crew to demonstrate the value of a trip through both the quantity and quality of the catch (Holland et al., 1992). However, recreational angler surveys consistently rank catch and retention of fish below intangibles, such as freedom to fish and camaraderie (Ditton et al., 1978; Holland and Ditton, 1992; Bochenek et al., 2012).

Harvest restrictions have intensified over time but current reef fish regulations do not directly restrict the freedom to fish because no effort limits have been imposed. Johnston et al. (2007) advocated a "rightsbased" approach to managing recreational fisheries in the northern GOM that would be facilitated by har- 
vest tags similar to those commonly used in terrestrial wildlife management. However, recreational fishermen may view a rights-based system unfavorably if such a system restricted the freedom to fish. In any case, managing the recreational reef fish fishery with a focus on discard reduction will require changes in fishermen's perceptions of the act of fishing as a human disturbance (Arlinghaus et al., 2007). However, significant changes in the attitudes of fishermen have been successfully implemented in other countries and could be adapted to fisheries in the northern GOM fisheries as well (Catchpole et al., 2005; Johnston et al., 2007; Granek et al., 2008).

\section{Acknowledgments}

Funding for this work was provided by the National Marine Fisheries Service's Cooperative Research Program (NA09NMF4540137) to W. Patterson. We gratefully acknowledge the charter boat captains and crews for their participation and invaluable cooperation throughout this study. We also thank J. Tarnecki and M. Norberg for their help with sampling.

\section{Literature cited}

Alverson, D. L., M. H. Freeberg, J. G. Pope, and S. A. Murawski. 1994. A global assessment of fisheries bycatch and discards. FAO Fish. Tech. Pap. 339, 233 p.

Anderson, M. J., R. N. Gorley, and K. R. Clarke. 2008. PERMANOVA+ for PRIMER: guide to software and statistical methods, 214 p. PRIMER-E: Plymouth, UK.

Arlinghaus, R., S. J. Cooke, A. Schwab, and I. G. Cowx.

2007. Fish welfare: a challenge to the feelings-based approach, with implications for recreational fishing. Fish Fish. 8:57-71.

Beamish, R. J. and D. A. Fournier.

1981. A method for comparing the precision of a set of age determinations. Can. J. Fish. Aquat. Sci. 38: 982-983.

Bochenek, E. A., E. N. Powell, J. DePersenaire, and S. E. King. 2010. Evaluating catch, effort, and bag limits on directed trips in the recreational summer flounder party boat fishery. Mar. Coast. Fish. 2:412-423.

Bochenek, E. A., E. N. Powell, and J. DePersenaire.

2012. Recall bias in recreational summer flounder party boat trips and angler preferences to new approaches to bag and size limits. Fish. Sci.78:1-14.

Catchpole, T. L., C. L. J. Frid, and T. S. Gray.

2005. Discards in North Sea fisheries: causes, consequences and solutions. Mar. Policy. 29(5):421-430.

Campbell, M. D., R. Patino, J. Tolan, R. Strauss, and S. L. Diamond.

2010. Sublethal effects of catch-and-release fishing: measuring capture stress, fish impairment, and predation risk using a condition index. ICES J. Mar. Sci. 667:513-521.

Campbell, M. D., W. B. Driggers III, B. Sauls, and J. F. Walter. 2014. Release mortality in the red snapper (Lutjanus campechanus) fishery: a meta-analysis of 3 decades of research. Fish. Bull. 112:283-296.
Coggins Jr., L. G., M. J. Catalano, M. S. Allen, W. E. Pine III, and C. J. Walters.

2007. Effects of cryptic mortality and the hidden costs of using length limits in fishery management. Fish Fish. 8:196-210.

Coleman F. C., W. F. Figueira, J. S. Ueland, and L. B. Crowder. 2004. The impact of United States recreational fisheries on marine fish populations. Science 305:1958-1960.

Cowan Jr., J. H., C. B. Grimes, W. F. Patterson III, C. J. Walters, A. C. Jones, W. J. Lindberg, D. J. Sheehy, W. E. Pine, J. E. Powers, M. D. Campbell, K. C. Lindeman, S. L. Diamond, R. Hilborn, H. T. Gibson, and K. A. Rose.

2011. Red snapper management in the Gulf of Mexico: science- or faith-based? Rev. Fish Biol. Fish. 21:187-204.

Crawley, M. J.

2007. The R book, 949 p. John Wiley \& Sons, Ltd., West Sussex, UK.

Dance, M. A., W. F. Patterson III, and D. T. Addis.

2011. Factors affecting reef fish community structure at unreported artificial reef sites off northwest Florida. Bull. Mar. Sci. 87:301-324.

Ditton, R. B., T. J. Mertens, and M. P. Schwartz.

1978. Characteristics, participation, and motivations of Texas charter boat fishermen. Mar. Fish. Rev. 40(8):8-12.

FAO.

1995. Code of conduct for responsible fisheries, $41 \mathrm{p}$. FAO, Rome. [Available from http://www.fao.org/docrep/005/v9878e/v9878e00.htm.]

Federal Register.

2012. Magnuson-Stevens Act provisions: definitions, 50 C.F.R. 600.10. [Available from http://cfr.regstoday. com/50CFR600.aspx.]

Granek, E. F., E. M. Madin, M. A. Brown, W. Figueira, D. S. Cameron, Z. Hogan, G. Kristianson, P. de Villers, J. E. Williams, J. Post, S. Zahn, and R. Arlinghaus.

2008. Engaging recreational fishers in management and conservation: global case studies. Conserv. Biol. 22(5):1125-1134.

GMFMC (Gulf of Mexico Fisheries Management Council).

2007 Final amendment 27 to the reef fish fishery management plan and amendment 14 to the shrimp fishery management plan, 380 p. [Available from Gulf of Mexico Fishery Management Council, 2203 North Lois Ave., Suite 1100, Tampa, FL 33607.]

Hanson, C. W., and B. Sauls.

2011. Status of recreational saltwater fishing in Florida: characterization of license sales, participation, and fishing effort. Am. Fish. Soc. Symp. 75:355-365.

Hoese, H. D., and R. H. Moore.

1998. Fishes of the Gulf of Mexico, Texas, Louisiana, and adjacent waters, 2nd ed, $416 \mathrm{p}$. Texas A\&M Univ. Press, College Station, TX.

Holland, S. M. and R. B. Ditton.

1992. Fishing trip satisfaction: a typology of anglers. North Am. J. Fish. Manage. 12:28-33.

Holland, S. M., R. B. Ditton, and D. A. Gill.

1992. The U.S. Gulf of Mexico charter boat industry: activity centers, species targeted, and fisheries management opinions. Mar. Fish. Rev. 54(2):21-27.

Johnston, R. J., D. S. Holland, V. Maharaj, and T. W. Campson. 2007. Fish harvest tags: an alternative management approach for recreational fisheries in the US Gulf of Mexico. Mar. Policy 31:505-516. 
Kabacoff, R. I.

2011. R in action: data analysis and graphics with $\mathrm{R}$. 450 p. Manning Publications Co., Shelter Island, New York.

Kelleher, K.

2005. Discards in the world's marine fisheries. An update. FAO Fish. Tech. Pap. 470, 131 p.

Kennelly, S. J., and M. K. Broadhurst.

2002. By-catch begone: changes in the philosophy of fishing technology. Fish Fish. 3:340-355.

Magnuson-Stevens Fishery Conservation and Management Act (MSFCMA).

2007. Public Law 94-265. [Available from http://www. nmfs.noaa.gov/msa2005/docs/MSA_amended_msa\%20 _20070112_FINAL.pdf.]

Magnuson-Stevens Fishery Conservation and Management Act (MSFCMA).

2007. Final amendment 22 to the reef fish fishery management plan to set red snapper Sustainable Fisheries Act targets and thresholds, set a rebuilding plan, and establish bycatch reporting methodologies for the reef fish fishery, 242 p. [Available from Gulf of Mexico Fishery Management Council, 2203 North Lois Ave, Suite 1100, Tampa, FL 33607.]

Matsuoka, T.

2008. A review of bycatch and discard issue toward solution. In Fisheries for global welfare and environment: memorial book of the 5th World Fisheries Congress (K. Tsukamoto, T. Kawamura, T. Takeuchi, T. D. Beard Jr., and M. J. Kaiser, eds.), p. 169-180. TerraPub, Tokyo.

NMFS (National Marine Fisheries Service).

2011. U.S. national bycatch report (W. A. Karp, L. L. Desfosse, S. G. Brooke, eds.), NOAA Tech. Memo. NMFSF/SPO-117E, 508 p.

Patterson, K., R. Cook, C. Darby, S. Gavaris, L. Kell, P. Lewy,

B. Mesnil, A. Punt, V. Restrepo, D. W. Skagen, and G.

Stefansson.

2001a. Estimating uncertainty in fish stock assessment and forecasting. Fish Fish. 2:125-157.

Patterson, W. F., III, J. H. Cowan Jr., C. A. Wilson, and R. L. Shipp.

2001b. Age and growth of red snapper, Lutjanus campechanus, from an artificial reef area off Alabama in the northern Gulf of Mexico. Fish. Bull. 99:617-627.
Patterson III, W. F., C. E. Porch, J. H. Tarnecki, and A. J. Strelcheck.

2012. Effect of circle hook size on reef fish catch rates, species composition, and selectivity in the northern Gulf of Mexico recreational fishery. Bull. Mar. Sci. 88:647-665.

Patterson, W. F., III, J. H. Tarnecki, D. T. Addis, and L. R. Barbieri.

2014. Reef fish community structure at natural versus artificial reefs in the northern Gulf of Mexico. Proc. Gulf Caribb. Fish. Inst. 66:4-8.

$\mathrm{R}$ Core Team.

2014. R: a language and environment for statistical computing. R Foundation for Statistical Computing, Vienna, Austria. [Available from http://www.r-project. org, accessed April 2014.]

Rummer, J. L.

2007. Factors affecting catch and release (CAR) mortalty in fish: Insight into CAR mortality in red snapper and the influence of catastrophic decompression. In red snapper ecology and fisheries in the U.S. Gulf of Mexico (W. F. Patterson, J. H. Cowan, G. R. Fitzhugh, and D. L. Nieland, eds.), p. 123-144. Am. Fish. Soc. Symp. 60, Bethesda, MD..

Sauls, B

2014. Relative survival of gags (Mycteroperca microlepis) released within a recreational hook-and-line fishery: Application of the Cox Regression Model to control for heterogeneity in a large-scale mark-recapture study. Fish. Res. 150:18-27.

Sauls, B. and O. Ayala.

2012. Circle hook requirements in the Gulf of Mexico: application in recreational fisheries and effectiveness for conservation of reef fishes. Bull. Mar. Sci. 88(3):667-679.

Waters, J. R., and G. R. Huntsman.

1986. Incorporating mortality from catch and release into yield-per-recruit analyses of minimum size limits. N. Am. J. Fish. Manage. 6:463-471.

Wilson, R. R., Jr., and K. M. Burns.

1996. Potential survival of released groupers caught deeper than $40 \mathrm{~m}$ based on shipboard and in-situ observations, and tag-recapture data. Bull. Mar. Sci. $58: 234-247$. 